\title{
Multinodular Goiter
}

National Cancer Institute

\section{Source}

National Cancer Institute. Multinodular Goiter. NCI Thesaurus. Code C131438.

Nodular goiter characterized by more than one discrete tissue mass. 